Discussion Paper No. 08-095

Alleviating Adverse Implications of EU Climate Policy on Competitiveness:

The Case for Border Tax Adjustments or the Clean Development Mechanism?

Victoria Alexeeva-Talebi, Niels Anger, and Andreas Löschel

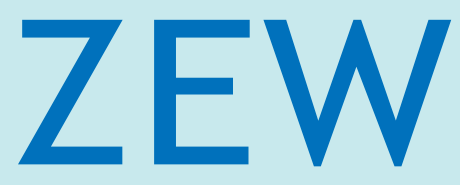

Zentrum für Europäische Wirtschaftsforschung $\mathrm{GmbH}$

Centre for European

Economic Research 
Discussion Paper No. 08-095

\title{
Alleviating Adverse Implications of EU Climate Policy on Competitiveness: The Case for Border Tax Adjustments or the Clean Development Mechanism?
}

\author{
Victoria Alexeeva-Talebi, Niels Anger, \\ and Andreas Löschel
}

Download this ZEW Discussion Paper from our ftp server:

ftp://ftp.zew.de/pub/zew-docs/dp/dp08095.pdf

Die Discussion Papers dienen einer möglichst schnellen Verbreitung von neueren Forschungsarbeiten des ZEW. Die Beiträge liegen in alleiniger Verantwortung der Autoren und stellen nicht notwendigerweise die Meinung des ZEW dar.

Discussion Papers are intended to make results of ZEW research promptly available to other economists in order to encourage discussion and suggestions for revisions. The authors are solely responsible for the contents which do not necessarily represent the opinion of the ZEW. 


\section{Non technical summary}

In March 2007, the European Council has agreed upon ambitious climate and energy policy targets for the period after the expiry of the Kyoto Protocol in the year 2012. It envisages reducing greenhouse gas emissions in the EU by 2020 by at least $20 \%$ compared to 1990 levels - and by $30 \%$ if other industrialized countries undertake similar efforts. Given large divergences among industrialized and developing countries on a potential post-Kyoto architecture, an international agreement on ambitious future abatement targets remains uncertain for the time being. Against this background, unilateral EU environmental policy has caused concerns about adverse competitiveness implications for European energy-intensive and export-oriented sectors. Employing a multi-sector, multi-region computable general equilibrium model of international energy use and global trade, we analyze the competitiveness implications of introducing border tax adjustments (BTA) and the Clean Development Mechanism (CDM) within the EU Emission Trading Scheme (EU ETS). Our quantitative simulation results demonstrate that alternative BTA regimes are suitable to alleviate adverse competiveness implications of unilateral European climate policy on energyintensive and export-oriented industries. However, the regulatory protection of these industries via subsidies for EU exporters and tariffs for non-EU importers goes at the expense of sectors which are excluded from the EU ETS. Our simulations further indicate that even restricted CDM access for EU ETS participants induces comparable output effects for EU energy-intensive and export-oriented sectors as the most ambitious BTA regime. Increasing "where-flexibility" of emission abatement for EU ETS participants via limited access to the CDM can thus be an attractive market-based alternative to the application of border tax adjustments for alleviating adverse competitiveness impacts of unilateral climate policy.

\section{Das Wichtigste in Kürze}

Der Ministerrat der Europäischen Union hat sich im März 2007 zu einer ambitionierten Klimapolitik verpflichtet: Falls kein internationales Klimaschutzabkommen für die Zeit nach dem Kyoto-Protokoll zustande kommt, sollen die Treibhausgas-Emissionen der EU bis zum Jahr 2020 um 20\% gegenüber 1990 reduziert werden. Eine solche unilaterale EUKlimapolitik könnte jedoch die europäische Wettbewerbsfähigkeit beeinträchtigen und ihre Umweltwirksamkeit durch die Verlagerung energieintensiver Industrien ins nichteuropäische Ausland unterlaufen. Zur Abfederung dieser Effekte können Politikmaßnahmen wie Umweltzölle („Border Tax Adjustments”) oder projektbasierte Emissionsreduktionen in Entwicklungsländern („Clean Development Mechanism”) im EU-Emissionshandelssystem (EU ETS) eingesetzt werden. Mit Hilfe eines multiregionalen und multisektoralen berechenbaren allgemeinen Gleichgewichtsmodells der Weltwirtschaft untersucht dieses Papier die makroökonomischen Implikationen beider Politikmaßnahmen. Die quantitativen Simulationsergebnisse zeigen, dass Umweltzölle ein geeignetes Instrument zur Abfederung der negativen Effekte auf die europäische Wettbewerbsfähigkeit darstellen. Allerdings geht eine solche Kompensation durch Umweltzölle zu Lasten der Sektoren, die vom EUEmissionshandel ausgenommen sind. Die Simulationen zeigen zudem, dass ein beschränkter Zugang zu projektbasierten Emissionsreduktionen in Entwicklungsländern vergleichbare Produktionseffekte für energie- und exportintensive Industrien der EU impliziert wie das anspruchsvollste Umweltzoll-Regime. Die Ermöglichung regionaler Flexibilität der Emissionsvermeidung mit Hilfe des „Clean Development Mechanism” kann somit eine attraktive marktbasierte Alternative zur Erhebung von Umweltzöllen darstellen, um die nachteiligen ökonomischen Auswirkungen unilateraler Klimapolitik abzufedern. 


\title{
Alleviating Adverse Implications of EU Climate Policy on Competitiveness: The Case for Border Tax Adjustments or the Clean Development Mechanism?
}

\author{
Victoria Alexeeva-Talebi, Niels Anger and Andreas Löschel \\ Centre for European Economic Research (ZEW) \\ P.O. Box 1034 43, 68034 Mannheim, Germany \\ E-mails: alexeeva-talebi@zew.de, anger@zew.de, loeschel@zew.de
}

\begin{abstract}
Ambitious unilateral EU environmental policy has raised concerns about adverse competitiveness implications for European energy-intensive and export-oriented sectors. We analyze the economic and environmental implications of two different measures to address these concerns in the EU Emission Trading Scheme (EU ETS): border tax adjustments (BTA) and the Clean Development Mechanism (CDM). Numerical simulations with a computable general equilibrium model of the global economy demonstrate that alternative BTA regimes are suitable to alleviate adverse competiveness implications of unilateral European climate policy on energy-intensive and export-oriented industries. The regulatory protection of these industries via subsidies for EU exporters and tariffs for non-EU importers goes, however, at the expense of sectors which are excluded from the EU ETS. We show that the choice of alternative benchmarks (i.e. carbon intensities) for the level of BTA substantially affects these competitiveness implications. The simulations further indicate that limited access to low-cost emission abatement via the CDM in the EU ETS alleviates adverse competitiveness impacts to a comparable extent as the most ambitious BTA scheme. Increasing "where-flexibility" of emission abatement thus represents an attractive market-based alternative to the application of border tax adjustments in unilateral climate policy.
\end{abstract}

JEL Classification: D58, F18, H23, Q48

Keywords: Emissions Trading, EU ETS, Competitiveness, Border tax adjustments, Clean Development Mechanism, CGE model 


\section{Introduction}

The European Union has recently started reforming regulations related to its future energy and climate policy in general and to the European Emission Trading System (EU ETS) in particular. In March 2007, the European Council has agreed upon ambitious climate and energy policy targets for the period after the expiry of the Kyoto Protocol in the year 2012. It envisages reducing greenhouse gas emissions in the EU by 2020 by at least $20 \%$ compared to 1990 levels, and by 30\% if other industrialized countries undertake similar efforts. In January 2008, the European Commission presented a comprehensive legislative package intended to implement the ambitious goals formulated by the European Council for the year 2020 (EU, 2008, 2008a). The package consists of new regulations for the third trading period within the European Emission Trading Scheme (ETS), a decision defining national emission targets for the sectors excluded from the Emission Trading Scheme (NETS sectors) and finally new regulations to promote the use of energy from renewable sources and to support the development of carbon capture and sequestration (CCS).

Given large divergences among industrialized and developing countries on the Post-Kyoto architecture, an international agreement on ambitious future abatement targets remains rather uncertain for the time being. Ambitious unilateral EU environmental policy causes concerns about adverse competitiveness implications for European energy-intensive and exportoriented sectors. As a remedy, the European Parliament has recently proposed to consider border tax adjustments (BTA) for third countries which are not foreseen by the Kyoto Protocol (European Parliament, 2007). Border measures are also mentioned in the proposal by the European Commission. The European legislation linking the EU ETS with the Kyoto Protocol's project-based mechanisms allows European companies to generate potentially lowcost emission reductions by means of the CDM (EU, 2004). Thus, the access to the Clean Development Mechanism (CDM) is in principle suitable to alleviate competitive disadvantages of European producers. However, some limits may apply to the use of CDM credits in order to assure that emission abatement in third countries remains supplemental to domestic action (see Anger, 2008, for the case of linking the EU ETS internationally).

The most recent CGE-related literature has mainly focused on assessing competitiveness effects associated with the implementation of the EU ETS (Bollen et al., 2003; Klepper and Peterson, 2004; COWI, 2004; Reinaud, 2005; Peterson, 2006; Alexeeva-Talebi and Anger, 2007). Contributions in the field of environmental economics discuss border tax adjustments 
(BTA) in the context of climate policy under the Kyoto Protocol and as a complementary policy measure of the EU ETS (Mathiesen and Maestad; 2004, Babiker and Rutherford, 2005; Demailly and Quirion, 2006; Ismer and Neuhoff, 2007; Peterson and Schleich, 2007). Alexeeva-Talebi et al. (2008) introduce the concept of integrating importers into the EU ETS showing that while BTA regulation protects the competitiveness of EU energy-intensive industries more effectively, the integration of importers induces larger emission reductions of foreign competitors.

Against this background, this paper analyzes the economic and environmental implications of two different measures to address adverse competitiveness implications from unilateral climate change policies, border tax adjustments and the Clean Development Mechanism, in the context of the third trading period of the EU ETS. Employing a multi-sector, multi-region computable general equilibrium (CGE) model of international energy use and global trade, we study the competitiveness implications of specific BTA designs for EU exporters and non-EU importers, as well as the role of alternative benchmarks for border tax adjustments. Furthermore, we analyze the competitiveness impacts of supplementarity rules in the EU ETS by assessing alternative CDM demand restrictions.

This article is structured as follows: Section 2 provides a description of our numerical model framework. Section 3 introduces climate policy scenarios for the year 2020. Section 4 presents the quantitative simulation results. Section 5 concludes.

\section{Numerical framework}

In the following, we present the quantitative framework of our analysis. We first introduce our modeling approach and then briefly discuss prerequisites for our policy assessment.

\subsection{Modelling approach}

For the numerical analysis, we employ a multi-sector, multi-region CGE model of international energy use and global trade. The model reflects the key features of the European ETS from a single country perspective: EU Member States are committed to specific carbon emissions constraints $\bar{E}_{r}$ which are agreed upon. Each of these countries must specify a cap $\overline{e_{r}^{E T S}}$ and the allocation rule for free emissions allowances to energy-intensive installations in sectors that are eligible for international emissions trading. Assuming that the EU trading 
systems cover only energy-intensive industries implies that complementary domestic abatement policies are necessary for the non-covered sectors in order to comply with the remaining national emissions budget $\left(\bar{E}_{r}-\overline{e_{r}^{E T S}}\right)$.

Figure 1 provides a diagrammatic structure of the open-economy CGE model used for comparative-static impact analysis of BTA and CDM regimes. For details and an algebraic formulation of the core model see Böhringer and Lange (2005). A representative agent $R A_{r}$ in each region $r$ is endowed with labour $\bar{L}_{r}$, capital $\bar{K}_{r}$, and fossil-fuel resources $\bar{Q}_{f f, r}$ which may be used for fossil fuel production. The representative agent maximizes utility from consumption of a composite good $C_{r}$ which combines demands for energy and non-energy commodities at a constant-elasticity-of-substitution (CES). Production $Y_{\text {ir }}$ of commodities $i$ in region $r$ is described by nested separable CES functions with the price-dependent use of capital, labour, energy and material in production. Carbon emissions are linked in fixed proportions to the emissions-relevant use of fossil fuels, while carbon abatement occurs by fuel switching or energy savings in production and final consumption. The modelling of international trade is based on the Armington approach of product heterogeneity (Armington, 1969), so that domestic and foreign goods of the same variety are distinguished by their origin. All goods used on the domestic market in intermediate and final demand correspond to a CES composite $A_{i r}$ that combines the domestically produced variety $Y_{i r}$ and imports $M_{i r}$ of the same variety from other regions. Domestic production $Y_{i r}$ either enters the formation of the Armington good $A_{i r}$ or is exported $\left(X_{i r}\right)$ to other regions to satisfy their import demand. Trade with other regions is represented by a set of horizontal export demand and import supply functions at exogenous world import and export prices. A balance of payment constraint, which is warranted through flexible exchange rates, incorporates the benchmark trade deficit or surplus.

The model is based on consistent accounts of national production and consumption, trade and energy flows for 2001 as provided by the GTAP 6 database (Dimaranan and McDougall, 2006). The forward calibration of the 2001 economies to the target year 2020 is based on energy trends for EU Member States (EU, 2003) and on international energy projections for non-European economies (US Department of Energy, 2005). 


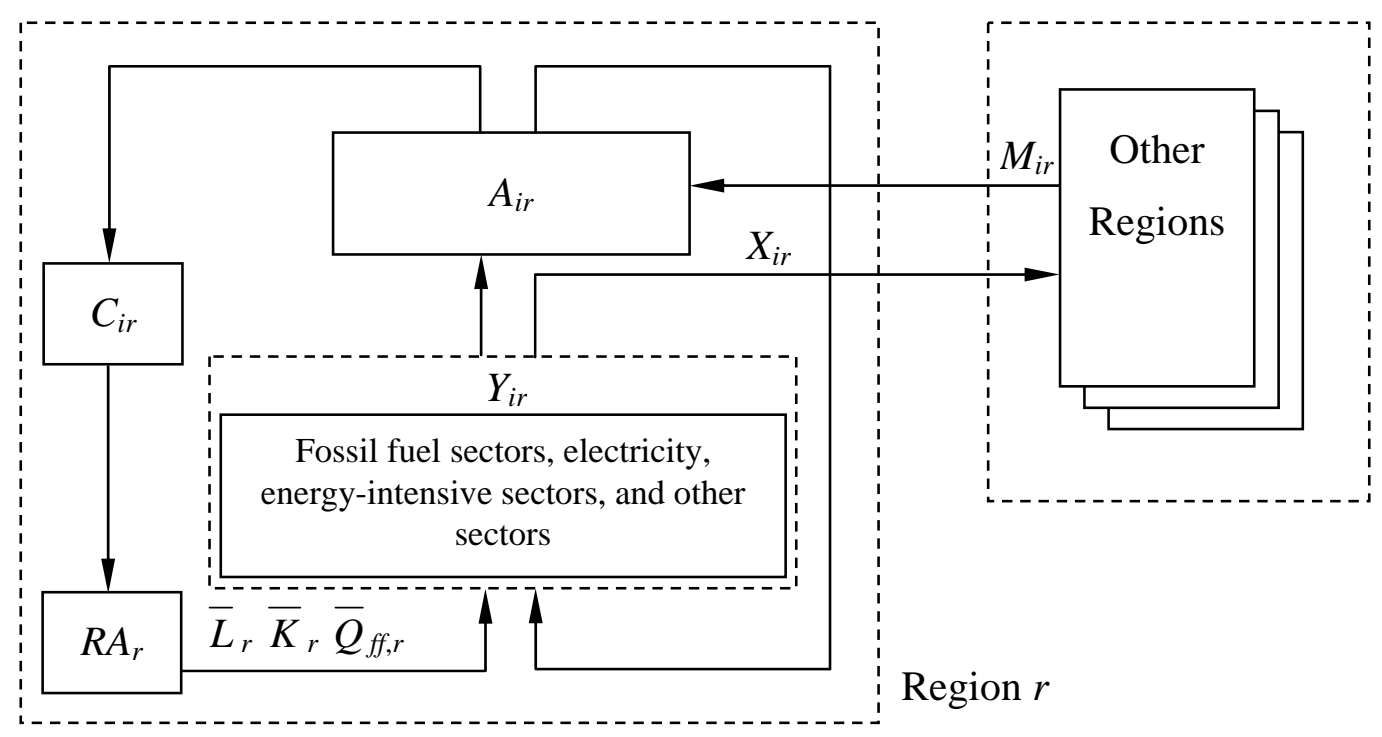

Figure 1: Diagrammatic overview of the model structure

Table 1 summarizes the regional and sectoral aggregation of the model. The regional aggregation of the GTAP database includes nine regions that are central in the climate policy debate on competitiveness and leakage. The sectoral aggregation in the model has been chosen to distinguish energy-intensive sectors from the rest of the economy. It captures key dimensions in the analysis of greenhouse gas abatement, such as differences in carbon intensities and the degree of substitutability across carbon-intensive goods. The primary and secondary energy goods identified in the model are coal, natural gas, crude oil, refined oil products, and electricity. The EU-wide emission trading system is restricted to eight ETS sectors (electricity, oil refineries, iron and steel, non-ferrous metals, mineral industries, paper and pulp production, air transportation and chemicals) as foreseen under the proposal to amend the current EU emissions trading scheme (EU, 2008a). The remaining sectors are aggregated to a composite industry that produces a non-energy-intensive macro good (NETS). Across all BTA policy scenarios, only four energy-intensive and export-oriented sectors within the EU ETS are subject to the BTA scheme: iron and steel, non-ferrous metals, mineral industries and paper and pulp production. We label these sectors with ETS_BTA, while the remaining industries covered by the EU ETS and which are not subject to the BTA scheme are named ETS_NBTA. Those sectors not part of the EU ETS are denoted as NETS (Table 1). 
Table 1: Model dimensions

\begin{tabular}{|cl|cl|}
\hline \multicolumn{2}{|c|}{ Production sectors } & Countries and Regions \\
\hline Energy & & EU regions \\
COA & Coal & EU15 $\quad$ Old Member States \\
CRU & Crude oil & EU12 $\quad$ New Member States \\
GAS & Natural gas & & \\
OIL & Refined oil products (ETS_NBTA) & & \\
ELE & Electricity (ETS_NBTA) & & \\
Energy-intensive sectors & Non-EU countries and regions \\
ORE & Ferrous metals (ETS_BTA) & OOE & Rest of OECD \\
PPP & Paper products and publishing & RUS & Former Soviet Union \\
& (ETS_BTA) & SMA & Rest of South and Middle America \\
NMM & Mineral products nec (ETS_BTA) & CHN & China (including Hongkong) \\
NFM & Metals nec (ETS_BTA) & SEA & Rest of South and East Asia \\
ATP & Air transport (ETS_NBTA) & OPC & OPEC \\
CRP & Chemicals, rubber and plastics & XRW & Rest of the World \\
& (ETS_BTA) & & \\
Non-energy-intensive sectors & & \\
ROI & Rest of industry (NETS) & & \\
CGD & Savings good & & \\
\hline
\end{tabular}

\subsection{Emission reduction targets}

In January 2008, the European Commission has adopted a Proposal to amend the current EU ETS Directive. This Proposal is part of draft legislation implementing the Integrated Energy Climate Change Package, endorsed by the European Council in March 2007 to limit the rise in global average temperature to no more than $2^{\circ}$ Celsius above pre-industrial levels. Thereby, the Proposal foresees the uniform emission reduction of 21 percent below 2005 emissions for the EU ETS sectors (ETS sectors) in all Member States by 2020 (EU, 2008). Commission's Climate Action and Renewable Energy Package of January 2008 contains furthermore the Proposal for a Decision on the commitments of Member States to reduce the greenhouse gas emissions up to 2020 (the so-called "Effort Sharing Decision”) (EU, 2008a). This Proposal determines heterogeneous contributions of Member States to meeting the EU greenhouse gas emission reduction commitment up to 2020 (in relation to the 2005 emissions level) in sectors not covered under the EU ETS Directive (NETS sectors). 
Table 2 illustrates effective emission reduction targets that apply to the ETS and NETS sectors in new and old EU Member States. The effective emission reduction targets are derived using the data from the Commission’s Impact Assessment for the years 1990, 2005 and 2020 (EU, 2008b). A uniform emission reduction target of 21 percent for the ETS sectors (compared to the 2005 emissions level) would correspond to an emissions reduction target of about 27.8 and 26.8 percent versus business-as-usual levels (BaU) in 2020 for the EU15 and EU12, respectively. Table 2 further depicts that burden imposed on the NETS sectors is relatively moderate in terms of effective emission reductions requirements in 2020. The resulting total aggregate commitments versus BaU level would imply comparable effective reduction targets for old and new EU Member States in 2020 (22 and 20.4 percent, respectively).

Table 2: Effective emission reduction targets [\% vis-à-vis BaU in 1990, 2005 and 2020]

\begin{tabular}{|l|lll|llll|lll|}
\hline & \multicolumn{3}{|c|}{ ETS } & \multicolumn{3}{c|}{ NETS } & \multicolumn{3}{c|}{ TOTAL } \\
\cline { 2 - 10 } & 1990 & 2005 & 2020 & 1990 & 2005 & 2020 & 1990 & 2005 & 2020 \\
\hline EU15 & -17.6 & -21.0 & -27.8 & -8.5 & -13.8 & -16.1 & -12.9 & -17.3 & -22.0 \\
EU12 & -43.2 & -21.0 & -26.8 & -16.5 & 13.2 & -11.0 & -33.6 & -8.4 & -20.4 \\
EU27 & -24.9 & -21.0 & -27.6 & -10.0 & -10.2 & -15.3 & -17.8 & -15.7 & -21.7 \\
\hline
\end{tabular}

Source: EU (2008b) and own calculations

Finally, all non-EU regions are assumed to not having committed to binding emissions reduction targets in 2020.

\section{Policy scenarios}

In order to assess the competitiveness impacts of unilateral EU emission regulation with border tax adjustments and the CDM, we introduce climate policy scenarios for the year 2020 . The ETS sectors are assumed to be allocated tradable allowances, while the remaining industries (NETS) have to be regulated via domestic carbon tax in order to meet the national emissions reduction targets in 2020. The regulation stringency in the EU is represented by the underlying regional effective emissions reduction targets in 2020 as presented in the previous section. In contrast, all non-EU regions are assumed to refrain from quantitative emission reduction commitments. Table 3 presents the set of climate policy scenarios for the year 2020 . 
Table 3: Climate policy scenarios for 2020

\begin{tabular}{|c|c|c|c|c|}
\hline Scenario & EU ETS & $\underset{\text { export subsidy }}{E U}$ & $\begin{array}{c}\text { Non-EU } \\
\text { import tariff }\end{array}$ & $\begin{array}{c}\text { CDM } \\
\text { Access }\end{array}$ \\
\hline ETS & Yes & No & No & No \\
\hline BTA_EX & Yes & Yes & No & No \\
\hline BTA_IM & Yes & No & Yes & No \\
\hline BTA_EXIM & Yes & Yes & Yes & No \\
\hline ETS_CDM10 & Yes & No & No & $\begin{array}{l}10 \% \text { of emission } \\
\text { reduction } \\
\text { requirement }\end{array}$ \\
\hline ETS_CDM41 & Yes & No & No & $\begin{array}{l}41 \% \text { of emission } \\
\text { reduction } \\
\text { requirement }\end{array}$ \\
\hline
\end{tabular}

As a reference case, scenario ETS reflects the upcoming European emission trading scheme in 2020, without any complementary measures to mitigate negative competitiveness impacts on European energy-intensive and export-oriented industries.

In scenarios labelled BTA, we introduce three alternative regimes of border tax adjustments into the EU ETS. Under BTA_EX, only EU exporters receive a subsidy, while importers into the EU are not regulated. Under BTA_IM, non-EU importers into the European Union are charged, while EU exporters do not receive any compensation. Under BTA_EXIM, both compensation for EU exporters and tariffs for non-EU importers are applied to ETS_BTA industries. In our core scenarios, both the duty levied on imports and the rebate for the EU exports in the covered sectors are quantity-based, i.e. the BTA level is determined by the EU average carbon content in the production of the respective energy-intensive good. Thus, sector-specific tariffs (per unit of export and/or import) are calculated with the EU ETS allowance price and the EU average carbon content in the corresponding sector. Consequently, no information about carbon intensities of foreign producers is necessary in the core simulations. For the scenarios BTA_IM and BTA_EXIM we, however, additionally vary the carbon intensity to determine the level of the import tariff. In this case, we assess a BTA regime in which industrialized and developing importing countries face an import tariff based on the average carbon content of the corresponding energy-intensive good of industrialized and developing regions, respectively. 
Finally, we analyze the role of the CDM for the competitiveness implications of unilateral EU emission regulation. Regarding the access to project-based emission reductions, the Marrakech Accords to the Kyoto Protocol demands that "the use of the mechanisms shall be supplemental to domestic action” (UNFCCC, 2002). Besides the supplementarity issue under the Kyoto Protocol, there is a separate supplementarity debate regarding the EU ETS: The scheme's amending directive states that "CDM credits up to the remainder of the level which they were allowed in the second trading period (2008-12) should be allowed in the third trading period” (EU, 2008a) and thus abstracts from specifying a quantitative limit for the import of CDM credits. As a consequence, we specify two tentative cases with the (relatively) restricted and generous CDM access for those sectors covered by the EU ETS: Scenario ETS_CDM10 assumes that CDM imports are limited to only 10 percent of the effective emission reduction requirement of EU ETS sectors in the year 2020. Scenario ETS_CDM41 assumes that CDM imports are allowed to a higher percentage of the effective reduction requirement of EU ETS sectors. This level of supplementarity has been endogenously determined to mimic the production level losses in the EU 27 under the most ambitious BTA regime (BTA_EXIM). ${ }^{1}$ For comparability, all CDM scenarios abstract from any application of border tax adjustments.

\section{Simulation results}

In this section, we discuss the environmental and competitiveness implications of unilateral EU emission regulation in 2020. While the former are measured by changes in carbon emissions, the latter are approximated by impacts on macroeconomic production values (output changes) resulting from alternative climate policy regimes. The entire set of numerical simulation results is provided in the Appendix.

\subsection{EU benchmarks for BTA}

As the starting point, we focus on scenarios where the sector-specific level of BTA is determined by the EU average carbon content of production of the respective energy-intensive good. We first discuss the economic implications for the EU, before analyzing effects for the non-EU countries.

\footnotetext{
${ }^{1}$ Compare scenarios ETS_CDM41 and BTA_EXIM in Table 6 of the Appendix.
} 


\section{Impacts for the European Union}

Figure 2 illustrates environmental implications in the sectors of our main interest, i.e. the European ETS_BTA industries which are both part of the EU ETS and the BTA scheme, for old and new EU Member States.

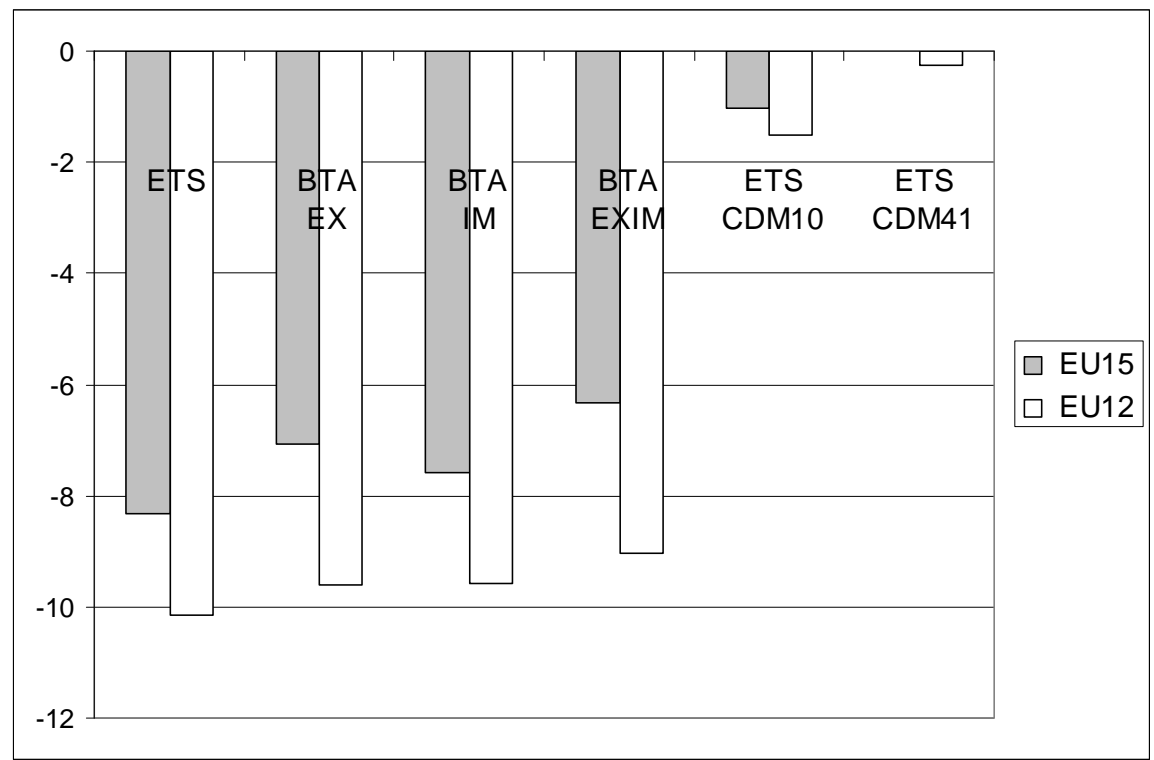

Figure 2: Adjustments in carbon emissions levels by European ETS_BTA sectors (\% vs. BAU)

Our results indicate that across all scenarios, the EU12 reduces a larger percentage of BAU emissions than the EU15, a result that reflects the relatively lower marginal abatement cost levels in new EU Member States. As a consequence, the EU12 exports emission allowances to the EU15 region that features relatively costly abatement options. Under the BTA regimes, however, energy-intensive and export-oriented sectors (ETS_BTA) in both regions increase production and associated carbon emissions in comparison to the pure EU ETS scheme, respectively. This is either due to subsidization of domestic output or taxation of competing foreign goods. Emission abatement decreases if non-EU importers are charged the import tariff (scenario BTA_IM), but to a smaller extent than in the case of tax compensations for EU exporters (scenario BTA_EX). This implies increasing both the carbon permit price in the EU ETS from 27 to 28 US\$ per ton of $\mathrm{CO}_{2}$ (see Table 4 in the Appendix), and the import of EU emission allowances from remaining energy-intensive industries (ETS_NBTA) which have hence to reduce a larger amount of emissions (see Table 5 in the Appendix). Obviously, the largest decrease in emission abatement occurs under BTA_EXIM. However, the emission reductions vary moderately across all three BTA regimes, ranging between roughly 6 and 10 percent. 
Regarding the environmental implications of the CDM access, Figure 3 implies that (granting) CDM access of only 10 percent of the effective emission reduction requirement for EU ETS sectors - in the absence of any BTA regulations - decreases domestic abatement of EU Member States to less than two percent of BAU emission levels (scenario ETS_CDM10). A larger share of the CDM within the EU ETS of up to 41 percent of the effective emission reduction requirement further reduces domestic carbon abatement. Obviously, the availability of low-cost emission reductions in developing countries induces carbon abatement shifting to these regions (see again Table 5). This effect is reflected by a substantial drop in the international permit price, amounting to 4.3 and 1.3 US\$ per ton of $\mathrm{CO}_{2}$ for CDM access of 10 and 41 percent, respectively.

We now turn to the associated competitiveness impacts of all alternative climate policy scenarios for European energy-intensive and export-oriented industries (ETS_BTA) which are measured as adjustments in the production level. Figure 3 illustrates output changes for old and new EU Member States across six scenarios.

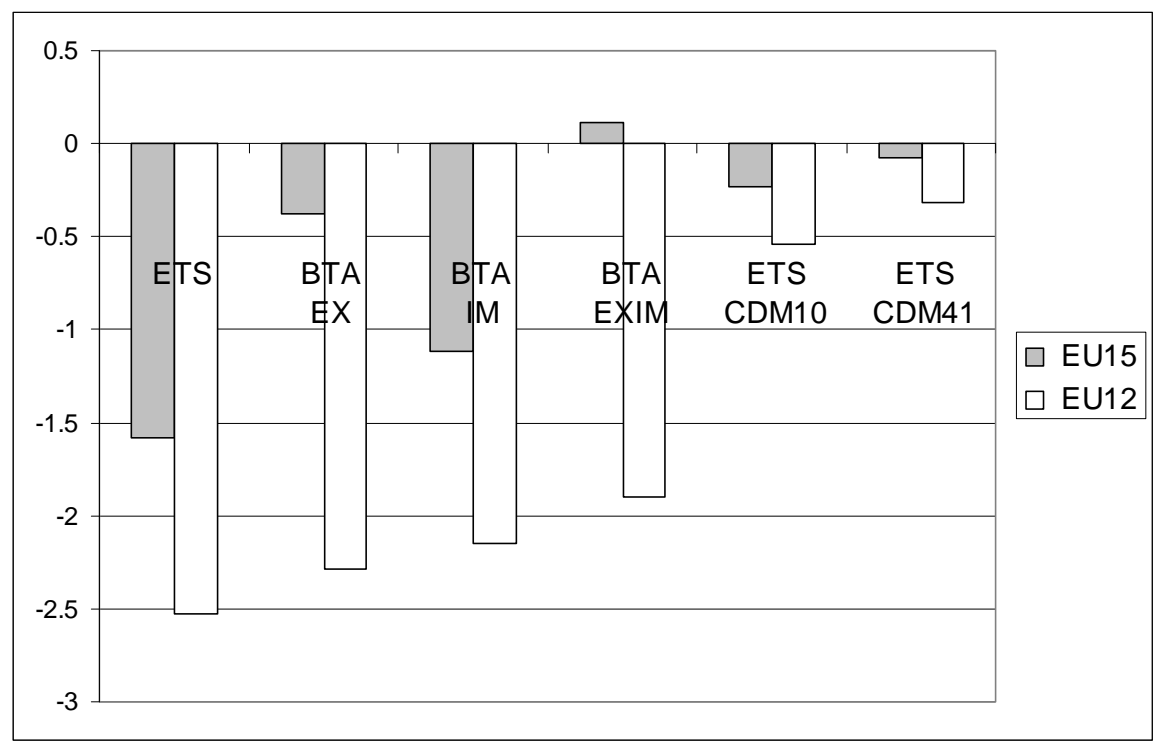

Figure 3: Output change for ETS_BTA sectors by EU region and scenario (\% vs. BAU)

As energy-related carbon emissions represent one of the main input factors into the production process, the output impacts from unilateral EU emission regulation - as displayed in the Figure 3 - are to a large extent consistent with the environmental impacts discussed above. First, the EU12 faces higher output losses than the EU15 across all policy scenarios. Second, regarding the alternative BTA regulations, we find output losses in European ETS_BTA sectors (in the EU27 aggregation) to be lower when EU exporters are subsidized 
than in the case of imposing a tariff on competing non-EU importers (see Table 5 in the Appendix). The lowest production losses for European ETS_BTA sectors are obviously induced by the combination of a subsidy for EU exporters and tariffs for non-EU importers. For the EU15, the output losses under a pure EU ETS even turn to output gains in scenario BTA_EXIM.

Our most interesting finding relates to the competitiveness implications of the CDM access. Figure 3 implies that granting even a restricted CDM access to EU ETS industries largely alleviates the negative competitiveness impacts from the unilateral emission regulation. The negative implications for the EU12 and EU15 are particularly low with a relatively generous access to the CDM projects (41 percent) - this scenario has been designed to mimic the production level losses in the EU 27 under the most ambitious BTA regime (BTA_EXIM). We find that the output losses in the EU12 and EU15 are in this case always lower than under almost all BTA regimes: The availability of low-cost emission reductions in developing countries decreases energy-related production costs of carbon regulation. But it does not induce output gains for European ETS_BTA sectors in the EU15 region. We conclude that increasing "where-flexibility" of emission abatement for EU ETS participants via (even limited) access to the CDM can be an attractive alternative to the application of border tax adjustments for alleviating adverse competitiveness impacts of unilateral climate policy.

Since our methodology allows to assess spillover effects to and market interactions with remaining industries, in Appendix (Table 5 and Table 6) we additionally report environmental and competitiveness implications for (i) those industries covered by the EU ETS and not subject to the BTA scheme (ETS_NBTA) and (ii) those sectors not part of the EU emission trading scheme (NETS). Table 5 first shows that European ETS_NBTA sectors reduce a much larger amount of their BAU emissions (between 25 and 30 percent) than the ETS_BTA industries of the EU (between 6 and 10 percent). This implies that those EU ETS industries that are regulated by border tax adjustments are importing a considerable amount of emission allowances from the remaining EU ETS sectors that feature lower marginal abatement cost level. Our results confirm the intuition that emissions abatement in European ETS_NBTA industries is hardly affected by alternative BTA regulations. However, as in the case of the ETS_BTA sectors, limited CDM access drastically decreases domestic abatement of EU Member States in these industries as well (as compared to a pure EU ETS). According to the Table 6, the associated competitiveness impacts of alternative climate policy scenarios for European ETS_NBTA industries reflect the effects on the emissions market: Output losses do not vary across BTA scenarios but remain at a comparably high level due to the high emission 
reduction requirements. In contrast, negative competitiveness effects are substantially alleviated by allowing CDM access to ETS_NBTA industries. For European non-energyintensive industries (NETS) that are excluded from EU emissions trading, neither alternative BTA regulations, nor limited CDM access for EU ETS sectors substantially affect emission abatement. Across all scenarios, the output effects in NETS sectors represent the mirror image to the output effects in ETS_BTA industries, albeit with a smaller variation. Thus, competitiveness gains (losses) of EU sectors that are subject to the BTA scheme go at the expense (are benefiting) those industries that are not part of EU ETS.

\section{Impacts for non-EU regions}

Besides environmental and competitiveness implications for the EU, Table 5 and Table 6 in the Appendix present simulation results for non-EU regions. Hereafter, we focus our discussion on the non-European ETS_BTA industries. We find out that unilateral EU climate policy increases carbon emission levels in regions beyond Europe. This is due to decreasing EU's demand for energy which causes the international price of fossil fuels to fall. This phenomenon is known as energy channel "carbon leakage". According to Table 5, the increase of emissions in non-EU regions remains at a rather moderate level across all scenarios. Further, Table 6 demonstrates that non-EU ETS_BTA sectors benefit from unilateral EU climate policy in terms of positive competitiveness implications: Across all BTA scenarios, non-EU regions feature production increases, most of all the Former Soviet Union (up to one percent) and the OPEC countries (up to 2 percent). Obviously, these positive output impacts are particularly small for the more extensive BTA regime (scenario BTA_EXIM). Importantly, under the CDM regulation, major developing countries face production losses in the respective sectors due to substantial emission reduction requirements from the European Union.

\subsection{Non-EU benchmarks for BTA}

Now we abstract from the assumption that the BTA level for industrialized and developing countries is based on the carbon content of the respective EU ETS sectors. Instead, we assume that the sector-specific BTA level for the former is based on the average carbon content in the production of the industrialized countries, while the tariffs for the latter is calculated with the average carbon content in the production of respective sectors in the developing countries. As 
new benchmarks apply to the import tariffs, only policy scenarios BTA_IM and BTA_EXIM might be affected by new parameters. Figure 4 contrasts output changes of European ETS_BTA industries for the cases of EU benchmarks and non-EU benchmarks (all quantitative results are compiled in Table 7 of the Appendix).

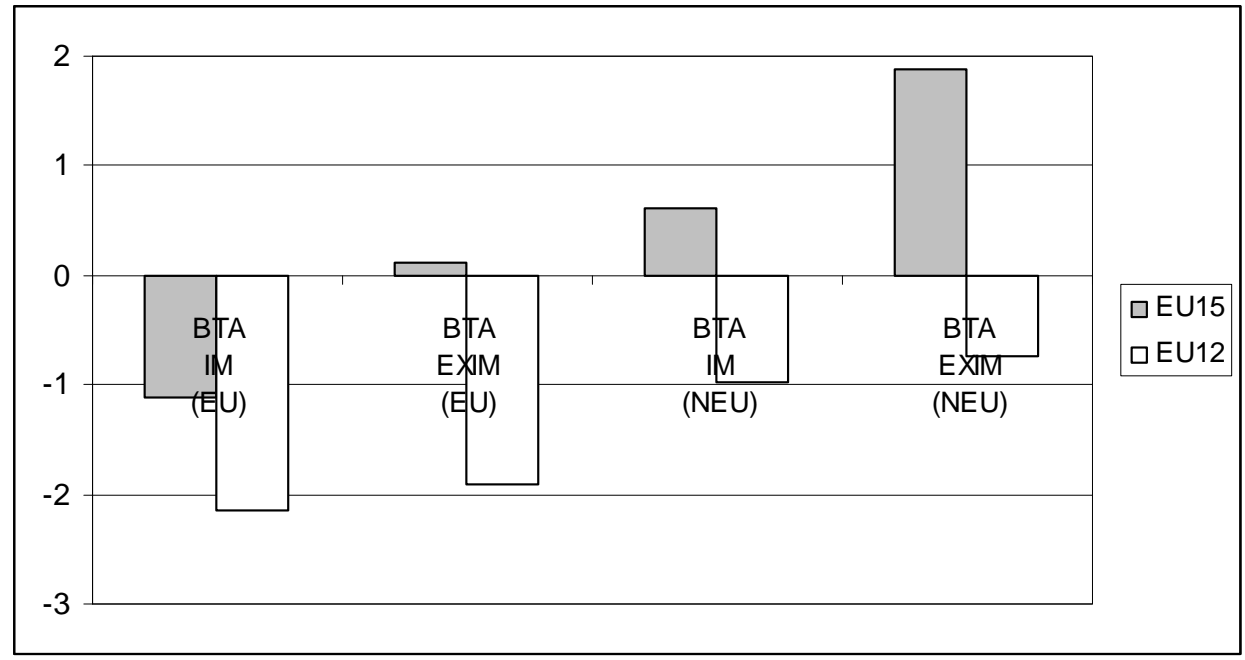

Figure 4: Output change for ETS_BTA sectors by EU region and BTA scenario (\% vs. BAU), contrasting EU benchmarks (EU) and non-EU benchmarks (NEU) for import tariffs

Our results demonstrate that the choice of regional benchmarks (i.e. carbon intensities) for an import tariff substantially affects competitiveness impacts of unilateral EU climate policy. For the EU12, output losses are considerably lower in the case of non-EU benchmarks, while for the EU15 negative competitiveness effects even turn to gains. This is due to the fact that the average carbon content of the respective energy-intensive goods in non-EU industrialized and developing regions is considerably higher than the EU average. As a consequence, the BTA tariff charged to non-EU importers is significantly higher in the case of non-EU benchmarks, which boosts the international competitiveness of the respective European industries. Focusing on the effects for the ETS_BTA industries in non-European regions (Table 6 to Table 7 in the Appendix), we detect that these industries face large competitiveness losses from the application of non-EU benchmarks as compared to EU average values.

\section{Conclusions}

In January 2008, the European Commission presented a comprehensive legislative package intended to implement the ambitious climate and energy policy goals formulated by the 
European Council for the year 2020, including new regulations for the third trading period of the European Emission Trading Scheme (ETS). Ambitious unilateral EU environmental policy evoked concerns about adverse competitiveness implications for European energyintensive and export-oriented sectors. As a remedy, the European Parliament has recently proposed to consider border tax adjustments (BTA) for third countries which are not foreseen by the Kyoto Protocol. The European Commission took up this proposal. Granting (a relatively generous) access to the Clean Development Mechanism (CDM) within the EU ETS might, however, represent a valuable alternative to border tax adjustments. Employing a multi-sector, multi-region computable general equilibrium (CGE) model of international energy use and global trade, we have analyzed the environmental and competitiveness implications of introducing border tax adjustments and the Clean Development Mechanism within the EU Emission Trading Scheme.

Our quantitative simulation results indicate that offsetting measures under consideration (i.e. BTA and the CDM) differ with respect to their impact on the European carbon market: While the application of border tax adjustments within the EU ETS slightly increases demand for emission allowances in the regulated sectors and the carbon permit price, the associated environmental impacts remain rather limited. In contrast, granting access to low-cost abatement options of the CDM to EU ETS participants decreases domestic abatement of EU Member States substantially and causes a drop in the allowance price.

Regarding the competitiveness implications of alternative BTA schemes, we find that output losses in the European energy-intensive and export-oriented sectors are particularly low if the most extensive BTA scheme (i.e. a combination of a subsidy for EU exporters and tariffs for non-EU importers) is applied. Among the unidirectional BTA regimes, the next best option for the EU15 would include subsidizing the EU exporters, while levying tariffs on non-EU importers appears to be more attractive for the EU12. However, we also demonstrate that the choice of (alternative) benchmarks (i.e. carbon intensities) for the level of a BTA-related import tariff might substantially affect the competitiveness implications of unilateral EU climate policy. Applying BTA benchmarks based on (relatively high) non-EU carbon contents of the respective energy-intensive good alleviates output losses for the EU12 region to a much larger extent than the application of EU benchmarks, while for the EU15 region formerly negative competitiveness effects even turn to gains. In this case, both EU12 and EU15 would benefit more from levying tariffs on non-EU importers. 
In our simulations, (even a rather) limited CDM access for EU ETS participants induces lower output losses for the European energy-intensive and export-oriented sectors than under almost all BTA regimes. We conclude that increasing "where-flexibility" of emission abatement for EU ETS participants via limited access to the CDM can be an attractive alternative to the application of border tax adjustments for alleviating adverse competitiveness impacts of unilateral climate policy.

Our findings underline once more the importance of accounting for the spillover effects with the not-regulated industries. Particularly, we demonstrate that competitiveness gains of EU ETS sectors that are subject to the BTA scheme go at the expense those industries that are excluded from EU emissions trading.

The impact of unilateral EU climate policy on non-EU carbon emissions in the main competing sectors is characterized by increased energy demand in non-EU regions, as EU emission regulation causes the international price of fossil fuels to fall. However, this phenomenon of “carbon leakage” remains rather moderate and can be attenuated through BTA regulations. Carbon leakage is even more modest when CDM access is granted for the EU ETS sectors, as the associated emission reductions in developing countries largely outweigh the emission increases in industrialized regions. While the competing non-EU sectors benefit from unilateral EU climate policy in terms of competitiveness, these effects are alleviated by BTA regulations. In the case of CDM access for EU ETS sectors, major developing countries face production losses due to substantial emission reductions. 


\section{References}

Alexeeva-Talebi, V. and N. Anger (2007), Developing Supra-European Emissions Trading Schemes: An Efficiency and International Trade Analysis, ZEW Discussion Paper No. 07-038, Mannheim.

Alexeeva-Talebi, V., Löschel A. and T. Mennel (2008), Climate Policy and the Problem of Competitiveness: Border Tax Adjustments or Integrated Emission Trading?, ZEW Discussion Paper No. 08-061, Mannheim.

Anger, N. (2008), Emissions Trading Beyond Europe: Linking Schemes in a Post-Kyoto World, Energy Economics 30(4), 2028-2049.

Armington, P.S. (1969), A Theory of Demand for Producers Distinguished by Place of Production, IMF Staff Papers 16, 159-178.

Babiker, M. and T. Rutherford (2005), The Economic Effects of Border Measures in Subglobal Climate Agreements, The Energy Journal 26(4), 99-125.

Böhringer, C. and A. Lange (2005), Economic implications of alternative allocation schemes for emission allowances, Scandinavian Journal of Economics 107(3), 563-581.

Bollen J., de Groot H., Manders T. and P. Tang (2003), The Kyoto Protocol and EU competitiveness, Paper prepared for the 6h GTAP Conference, The Hague, 12-14 June 2003.

COWI (2004), Competitiveness and EU Climate Change Policy, Interim Report COWI for UNICE.

Demailly, D. and P. Quirion (2006), Leakage from climate policies and border tax adjustment: lessons from a geographic model of the cement industry, Working Paper CIRED, Nogent-sur-Marne.

Dimaranan, B.V. and R.A. McDougall (2006), Global Trade, Assistance, and Production: The GTAP 6 Data Base, Center for Global Trade Analysis, Purdue University, WestLafayette.

EU (2004), Directive 2004/101/EC, amending Directive 2003/87/EC establishing a scheme for greenhouse gas emission allowance trading within the Community, in respect of the Kyoto Protocol's project mechanisms. European Commission, Brussels. Available at: http://eur-lex.europa.eu/LexUriServ/site/en/oj/2004/1_338/1 33820041113en00180023.pdf 
EU (2008), Proposal for a Directive of the European Parliament and of the Council amending Directive 2003/87/EC so as to improve and extend the greenhouse gas emission allowance trading system of the Community, Communication COM(2008) 30 final, European Commission, Brussels.

EU (2008a), Proposal for a Decision of the European Parliament and of the Council on the effort of Member States to reduce their greenhouse gas emissions to meet the Community’s greenhouse gas emission reduction commitments up to 2020, European Commission, Brussels.

EU (2008b), Commission Staff Working Document, Impact Assessment, Document accompanying the Package of implementation measures fro the EU's objectives on climate change and renewable energy fro 2020, $\operatorname{Sec}(2008)$ 85/3. European Commission, Brussels. Available at: http://ec.europa.eu/energy/climate_actions/doc/2008_res_ia_en.pdf.

European Parliament (2007), Resolution on Trade and Climate Change of 29 November 2007”, EP Document P6TA (2007) 0576. Available at: http://www.europarl.europa.eu/sides/getDoc.do?pubRef=-//EP//TEXT+TA+P6-TA2007-0576+0+DOC+XML+V0//EN.

Ismer, R. and K. Neuhoff, (2007), Border tax adjustment: a feasible way to support stringent emission trading, European Journal of Law and Economics 24, 137-164.

Klepper, G. and S. Peterson (2004), The EU Emissions Trading Scheme: Allowance Prices, Trade Flows, Competitiveness Effects, Kiel Working Paper no 1195, Kiel Institute for World Economics, Kiel.

Mathiesen, M. and O. Maestad (2004), Climate policy and the steel industry: Achieving global emission reductions by an incomplete climate agreement, Energy Journal 25, 91-114.

Peterson, S (2006) The EU Emissions Trading Scheme and its Competitiveness Effects upon European Business Results from the CGE Model DART, Mimeo, Kiel Institute for World Economics, Kiel.

Peterson, E. B. and J. Schleich (2007), Economic and Environmental Effects of Border Tax Adjustments, Working Paper Sustainability and Innovation S1/2007, ISI Karlsruhe

Reinaud, J. (2005), Industrial Competitiveness under the European Union Emissions Trading Scheme. IEA Information Paper, Paris 
UNFCCC (2002), Report of the Conference of the Parties on its Seventh Session, Held at Marrakesh from 29 October to 10 November 2001. Part One: Proceedings. Available at: http://unfccc.int/resource/docs/cop7/13.pdf

US Department of Energy (2005), International Energy Outlook, Energy Information Administration. 


\section{Appendix: List of Tables}

Table 4: $\mathrm{CO}_{2}$ permit price for ETS sectors by region and scenario (\$US per ton of CO2)

\begin{tabular}{|c|c|c|c|c|c|c|}
\hline Region & ETS & $\begin{array}{c}\text { BTA } \\
\text { EX }\end{array}$ & $\begin{array}{c}\text { BTA } \\
\text { IM }\end{array}$ & $\begin{array}{c}\text { BTA } \\
\text { EXIM }\end{array}$ & $\begin{array}{c}\text { ETS } \\
\text { CDM10 }\end{array}$ & $\begin{array}{c}\text { ETS } \\
\text { CDM41 }\end{array}$ \\
\hline \multicolumn{7}{|l|}{ EU benchmarks } \\
\hline EU15 & 27.24 & 27.89 & 27.55 & 28.21 & 4.35 & 1.43 \\
\hline EU12 & 27.24 & 27.89 & 27.55 & 28.21 & 4.35 & 1.43 \\
\hline \multicolumn{7}{|c|}{ Non-Eu benchmarks } \\
\hline EU15 & 27.24 & 27.89 & 28.45 & 29.13 & 4.35 & 1.43 \\
\hline EU12 & 27.24 & 27.89 & 28.45 & 29.13 & 4.35 & 1.43 \\
\hline
\end{tabular}


Table 5: EU benchmarks - Carbon emissions change by region, sector and scenario (\% vs. BaU)

\begin{tabular}{|c|c|c|c|c|c|c|c|}
\hline Region & Sector & ETS & $\begin{array}{c}\text { BTA } \\
\text { EX }\end{array}$ & $\begin{array}{l}\text { BTA } \\
\text { IM }\end{array}$ & $\begin{array}{c}\text { BTA } \\
\text { EXIM }\end{array}$ & $\begin{array}{c}\text { ETS } \\
\text { CDM10 }\end{array}$ & $\begin{array}{c}\text { ETS } \\
\text { CDM41 }\end{array}$ \\
\hline \multirow{4}{*}{ EU15 } & Total & -22.34 & -22.32 & -22.34 & -22.32 & -12.89 & -11.00 \\
\hline & ETS_BTA & -8.31 & -7.06 & -7.59 & -6.34 & -1.03 & 0.00 \\
\hline & ETS_NBTA & -29.55 & -29.57 & -29.58 & -29.60 & -10.06 & -6.13 \\
\hline & NETS & -16.10 & -16.10 & -16.10 & -16.10 & -16.10 & -16.10 \\
\hline \multirow{4}{*}{ EU12 } & Total & -18.27 & -18.36 & -18.27 & -18.36 & -7.20 & -4.98 \\
\hline & ETS_BTA & -10.16 & -9.61 & -9.58 & -9.04 & -1.52 & -0.26 \\
\hline & ETS_NBTA & -25.26 & -25.52 & -25.36 & -25.62 & -5.16 & -1.06 \\
\hline & NETS & -11.00 & -11.00 & -11.00 & -11.00 & -11.00 & -11.00 \\
\hline \multirow{4}{*}{ EU27 } & Total & -21.70 & -21.70 & -21.70 & -21.70 & -12.00 & -10.06 \\
\hline & ETS_BTA & -9.07 & -8.11 & -8.41 & -7.45 & -1.23 & -0.11 \\
\hline & ETS_NBTA & -28.83 & -28.9 & -28.88 & -28.94 & -9.24 & -5.29 \\
\hline & NETS & -15.44 & -15.44 & -15.44 & -15.44 & -15.44 & -15.44 \\
\hline \multirow{4}{*}{$\begin{array}{l}\text { Rest of } \\
\text { OECD }\end{array}$} & Total & 0.71 & 0.69 & 0.70 & 0.68 & 0.40 & 0.34 \\
\hline & ETS_BTA & 0.72 & 0.41 & 0.56 & 0.26 & 0.66 & 0.62 \\
\hline & ETS_NBTA & 0.80 & 0.78 & 0.79 & 0.78 & 0.29 & 0.19 \\
\hline & NETS & 0.57 & 0.57 & 0.57 & 0.57 & 0.55 & 0.55 \\
\hline \multirow{4}{*}{$\begin{array}{l}\text { Former } \\
\text { Soviet } \\
\text { Union }\end{array}$} & Total & 1.14 & 1.03 & 1.07 & 0.97 & 1.32 & 1.02 \\
\hline & ETS_BTA & 1.61 & 1.01 & 1.30 & 0.71 & 1.42 & 1.35 \\
\hline & ETS_NBTA & 1.39 & 1.30 & 1.33 & 1.24 & 1.74 & 1.28 \\
\hline & NETS & 0.58 & 0.58 & 0.56 & 0.56 & 0.57 & 0.48 \\
\hline \multirow{4}{*}{$\begin{array}{l}\text { South and } \\
\text { Central } \\
\text { America }\end{array}$} & Total & 1.03 & 0.99 & 1.01 & 0.97 & 0.76 & 0.66 \\
\hline & ETS_BTA & 0.99 & 0.59 & 0.75 & 0.34 & 1.02 & 0.96 \\
\hline & ETS_NBTA & 2.14 & 2.12 & 2.13 & 2.10 & 1.41 & 1.17 \\
\hline & NETS & 0.16 & 0.17 & 0.17 & 0.18 & 0.20 & 0.20 \\
\hline \multirow{4}{*}{ China } & Total & 0.96 & 0.91 & 0.93 & 0.88 & -17.52 & -12.53 \\
\hline & ETS_BTA & 0.70 & 0.44 & 0.55 & 0.30 & -0.94 & -0.33 \\
\hline & ETS_NBTA & 1.25 & 1.19 & 1.21 & 1.15 & -18.31 & -11.86 \\
\hline & NETS & 0.34 & 0.36 & 0.35 & 0.37 & -19.89 & -17.19 \\
\hline \multirow{4}{*}{$\begin{array}{l}\text { Rest of } \\
\text { South and } \\
\text { East Asia }\end{array}$} & Total & 1.07 & 0.98 & 1.00 & 0.92 & -14.37 & -14.37 \\
\hline & ETS_BTA & 1.03 & 0.54 & 0.61 & 0.12 & -13.99 & -13.98 \\
\hline & ETS_NBTA & 1.17 & 1.10 & 1.13 & 1.05 & -19.35 & -19.38 \\
\hline & NETS & 0.88 & 0.91 & 0.90 & 0.92 & -5.14 & -5.08 \\
\hline \multirow{4}{*}{ OPEC } & Total & 0.98 & 0.88 & 0.92 & 0.81 & 0.66 & 0.55 \\
\hline & ETS_BTA & 2.68 & 1.92 & 2.29 & 1.52 & 2.49 & 2.36 \\
\hline & ETS_NBTA & 1.45 & 1.37 & 1.41 & 1.33 & 0.99 & 0.85 \\
\hline & NETS & 0.11 & 0.14 & 0.11 & 0.14 & -0.13 & -0.20 \\
\hline \multirow{4}{*}{$\begin{array}{l}\text { Rest of } \\
\text { World }\end{array}$} & Total & 2.10 & 1.87 & 1.92 & 1.70 & 2.26 & 1.72 \\
\hline & ETS_BTA & 2.58 & 1.20 & 1.64 & 0.29 & 3.58 & 2.84 \\
\hline & ETS_NBTA & 3.31 & 3.12 & 3.15 & 2.97 & 3.25 & 2.41 \\
\hline & NETS & 0.14 & 0.17 & 0.15 & 0.18 & 0.41 & 0.36 \\
\hline
\end{tabular}


Table 6: EU benchmarks - Output change by region, sector and scenario (\% vs. BaU)

\begin{tabular}{|c|c|c|c|c|c|c|c|}
\hline Region & $\begin{array}{l}\text { Scenario } \\
\text { Sector }\end{array}$ & ETS & $\begin{array}{c}\text { BTA } \\
\text { EX }\end{array}$ & $\begin{array}{l}\text { BTA } \\
\text { IM }\end{array}$ & $\begin{array}{c}\text { BTA } \\
\text { EXIM }\end{array}$ & $\begin{array}{c}\text { ETS } \\
\text { CDM10 }\end{array}$ & $\begin{array}{c}\text { ETS } \\
\text { CDM41 }\end{array}$ \\
\hline \multirow{4}{*}{ EU15 } & Total & -0.40 & -0.47 & -0.43 & -0.51 & -0.43 & -0.42 \\
\hline & ETS_BTA & -1.58 & -0.38 & -1.12 & 0.11 & -0.23 & -0.08 \\
\hline & ETS_NBTA & -10.28 & -10.14 & -10.23 & -10.10 & -2.76 & -1.69 \\
\hline & NETS & -0.39 & -0.47 & -0.43 & -0.51 & -0.43 & -0.42 \\
\hline \multirow{4}{*}{ EU12 } & Total & -0.15 & -0.18 & -0.19 & \begin{tabular}{|l|}
-0.22 \\
\end{tabular} & \begin{tabular}{|c|}
-0.14 \\
\end{tabular} & -0.14 \\
\hline & ETS_BTA & -2.53 & -2.29 & -2.15 & -1.90 & -0.54 & -0.32 \\
\hline & ETS_NBTA & -7.05 & -7.07 & -7.02 & -7.04 & -0.46 & 0.53 \\
\hline & NETS & -0.12 & -0.16 & -0.16 & -0.20 & -0.14 & -0.14 \\
\hline \multirow{4}{*}{ EU27 } & Total & -0.38 & -0.45 & -0.41 & -0.49 & -0.40 & -0.40 \\
\hline & ETS_BTA & -1.69 & -0.58 & -1.23 & -0.11 & -0.26 & -0.11 \\
\hline & ETS_NBTA & -9.54 & -9.44 & -9.49 & -9.40 & -2.24 & -1.18 \\
\hline & NETS & -0.37 & -0.44 & -0.41 & -0.48 & -0.40 & -0.40 \\
\hline \multirow{4}{*}{$\begin{array}{l}\text { Rest of } \\
\text { OECD }\end{array}$} & Total & 0.00 & 0.01 & 0.01 & 0.02 & 0.01 & 0.02 \\
\hline & ETS_BTA & 0.21 & -0.05 & 0.10 & -0.17 & 0.11 & 0.07 \\
\hline & ETS_NBTA & 0.75 & 0.72 & 0.73 & 0.71 & 0.26 & 0.17 \\
\hline & NETS & 0.00 & 0.01 & 0.01 & 0.02 & 0.01 & 0.02 \\
\hline \multirow{4}{*}{$\begin{array}{l}\text { Former } \\
\text { Soviet } \\
\text { Union }\end{array}$} & Total & 0.21 & 0.23 & 0.22 & 0.24 & 0.23 & 0.23 \\
\hline & ETS_BTA & 1.08 & 0.71 & 0.92 & 0.55 & 0.95 & 0.88 \\
\hline & ETS_NBTA & 0.95 & 0.84 & 0.88 & 0.78 & 0.45 & 0.37 \\
\hline & NETS & 0.19 & 0.22 & 0.20 & 0.23 & 0.22 & 0.22 \\
\hline \multirow{4}{*}{$\begin{array}{l}\text { South and } \\
\text { Central } \\
\text { America }\end{array}$} & Total & 0.03 & 0.06 & 0.05 & 0.07 & 0.06 & 0.07 \\
\hline & ETS_BTA & 0.45 & 0.10 & 0.27 & -0.09 & 0.32 & 0.27 \\
\hline & ETS_NBTA & 1.79 & 1.78 & 1.78 & 1.77 & 0.84 & 0.64 \\
\hline & NETS & 0.03 & 0.06 & 0.04 & 0.07 & 0.06 & 0.07 \\
\hline \multirow{4}{*}{ China } & Total & 0.04 & 0.06 & 0.05 & 0.08 & 0.02 & 0.04 \\
\hline & ETS_BTA & 0.18 & -0.04 & 0.03 & -0.19 & -0.14 & -0.03 \\
\hline & ETS_NBTA & 0.38 & 0.30 & 0.33 & 0.25 & -1.63 & -1.29 \\
\hline & NETS & 0.04 & 0.06 & 0.05 & 0.08 & 0.02 & 0.04 \\
\hline \multirow{4}{*}{$\begin{array}{l}\text { Rest of } \\
\text { South and } \\
\text { East Asia }\end{array}$} & Total & 0.03 & 0.06 & 0.05 & 0.08 & -0.07 & -0.06 \\
\hline & ETS_BTA & 0.65 & 0.08 & 0.30 & -0.27 & -2.82 & -2.88 \\
\hline & ETS_NBTA & 0.86 & 0.78 & 0.81 & 0.73 & -3.78 & -3.83 \\
\hline & NETS & 0.03 & 0.06 & 0.05 & 0.08 & -0.05 & -0.04 \\
\hline \multirow{4}{*}{ OPEC } & Total & 0.17 & 0.20 & 0.19 & 0.22 & 0.18 & 0.18 \\
\hline & ETS_BTA & 2.23 & 1.64 & 1.95 & 1.35 & 1.89 & 1.75 \\
\hline & ETS_NBTA & 1.87 & 1.81 & 1.83 & 1.78 & 0.98 & 0.79 \\
\hline & NETS & 0.16 & 0.19 & 0.18 & 0.21 & 0.17 & 0.17 \\
\hline \multirow{4}{*}{$\begin{array}{l}\text { Rest of } \\
\text { World }\end{array}$} & Total & 0.08 & 0.13 & 0.11 & 0.16 & 0.15 & 0.16 \\
\hline & ETS_BTA & 1.16 & 0.53 & 0.87 & 0.23 & 1.18 & 0.98 \\
\hline & ETS_NBTA & 2.77 & 2.58 & 2.61 & 2.43 & 1.43 & 1.05 \\
\hline & NETS & 0.07 & 0.12 & 0.10 & 0.16 & 0.14 & 0.16 \\
\hline
\end{tabular}


Table 7: Non-EU benchmarks - Carbon emissions and output change by region, sector and scenario

\begin{tabular}{|c|c|c|c|c|c|}
\hline Region & Sector & $\begin{array}{c}\text { BTA } \\
\text { IM }\end{array}$ & $\begin{array}{c}\text { BTA } \\
\text { EXIM }\end{array}$ & $\begin{array}{c}\text { BTA } \\
\text { IM }\end{array}$ & $\begin{array}{c}\text { BTA } \\
\text { EXIM }\end{array}$ \\
\hline & & \multicolumn{2}{|c|}{ Emissions change (\% vs. BaU) } & \multicolumn{2}{|c|}{ Output change (\% vs. BaU) } \\
\hline \multirow{4}{*}{ EU15 } & Total & -22.32 & -22.30 & -0.55 & -0.62 \\
\hline & ETS_BTA & -5.91 & -4.66 & 0.62 & 1.88 \\
\hline & ETS_NBTA & -29.63 & -29.65 & -10.06 & -9.92 \\
\hline & NETS & -16.10 & -16.10 & -0.55 & -0.63 \\
\hline \multirow{4}{*}{ EU12 } & Total & -18.35 & -18.45 & -0.30 & -0.33 \\
\hline & ETS_BTA & -8.41 & -7.89 & -0.98 & -0.73 \\
\hline & ETS_NBTA & -25.70 & -25.97 & -7.01 & -7.04 \\
\hline & NETS & -11.00 & -11.00 & -0.28 & -0.32 \\
\hline \multirow{4}{*}{ EU27 } & Total & -21.70 & -21.70 & -0.53 & -0.60 \\
\hline & ETS_BTA & -6.94 & -5.99 & 0.44 & 1.60 \\
\hline & ETS_NBTA & -28.97 & -29.04 & -9.36 & -9.26 \\
\hline & NETS & -15.44 & -15.44 & -0.53 & -0.61 \\
\hline \multirow{4}{*}{$\begin{array}{l}\text { Rest of } \\
\text { OECD }\end{array}$} & Total & 0.70 & 0.68 & 0.02 & 0.03 \\
\hline & ETS_BTA & 0.30 & -0.02 & -0.16 & -0.43 \\
\hline & ETS_NBTA & 0.79 & 0.77 & 0.72 & 0.70 \\
\hline & NETS & 0.58 & 0.58 & 0.02 & 0.04 \\
\hline \multirow{4}{*}{$\begin{array}{l}\text { Former } \\
\text { Soviet } \\
\text { Union }\end{array}$} & Total & 1.07 & 0.96 & 0.23 & 0.26 \\
\hline & ETS_BTA & 1.12 & 0.52 & 0.83 & 0.45 \\
\hline & ETS_NBTA & 1.36 & 1.26 & 0.86 & 0.76 \\
\hline & NETS & 0.57 & 0.57 & 0.22 & 0.25 \\
\hline \multirow{4}{*}{$\begin{array}{l}\text { South and } \\
\text { Central } \\
\text { America }\end{array}$} & Total & 0.88 & 0.84 & 0.10 & 0.12 \\
\hline & ETS_BTA & -0.01 & -0.40 & -0.45 & -0.82 \\
\hline & ETS_NBTA & 1.98 & 1.96 & 1.68 & 1.66 \\
\hline & NETS & 0.18 & 0.19 & 0.10 & 0.13 \\
\hline \multirow{4}{*}{ China } & Total & 0.84 & 0.79 & 0.11 & 0.13 \\
\hline & ETS_BTA & 0.33 & 0.08 & -0.50 & -0.72 \\
\hline & ETS_NBTA & 1.10 & 1.04 & 0.17 & 0.09 \\
\hline & NETS & 0.37 & 0.40 & 0.11 & 0.14 \\
\hline \multirow{4}{*}{$\begin{array}{l}\text { Rest of } \\
\text { South and } \\
\text { East Asia }\end{array}$} & Total & 0.76 & 0.68 & 0.13 & 0.16 \\
\hline & ETS_BTA & -0.68 & -1.16 & -1.28 & -1.85 \\
\hline & ETS_NBTA & 0.93 & 0.85 & 0.58 & 0.50 \\
\hline & NETS & 0.94 & 0.97 & 0.13 & 0.17 \\
\hline \multirow{4}{*}{ OPEC } & Total & 0.64 & 0.54 & 0.26 & 0.29 \\
\hline & ETS_BTA & 0.55 & -0.19 & 0.26 & -0.34 \\
\hline & ETS_NBTA & 1.20 & 1.13 & 1.65 & 1.60 \\
\hline & NETS & 0.14 & 0.18 & 0.25 & 0.29 \\
\hline \multirow{4}{*}{$\begin{array}{l}\text { Rest of } \\
\text { World }\end{array}$} & Total & 1.07 & 0.88 & 0.30 & 0.35 \\
\hline & ETS_BTA & -1.75 & -2.94 & -1.78 & -2.44 \\
\hline & ETS_NBTA & 2.20 & 2.04 & 1.75 & 1.60 \\
\hline & NETS & 0.18 & 0.21 & 0.31 & 0.36 \\
\hline
\end{tabular}

